\title{
VALUE CHAIN DRIVEN HUMAN CAPITAL DEVELOPMENT: AN EVIDENCE FROM AGRICULTURAL VALUE CHAINS IN KARNATAKA
}

\author{
Dr. Nagaraj BV ${ }^{1}$ and Dr. Y.T. Krishnegowda ${ }^{2}$ \\ ${ }^{1}$ Asst. Professor, Kirloskar Institute of Advanced Management Studies, Harihar \\ ${ }^{2}$ Professor \& HOD, Department of Mechanical Engineering, Professor \& HOD, Mysore
}

\begin{abstract}
Human capital development (HCD) among farmers is a fundamental issue for any developing agrarian economy. Though education is the prime factor influencing human development, the education provided by governments to the rural population alone cannot ensure HCD. It is proved in India by efficient working models like ICT's e-Choupal and modern agriculture with contract farming that well governed supply chain practice, development of value chain to serve different customers and transparent interface between markets and the farmer provide best opportunity for farmers to apply their knowledge (tacit and acquired) for their social and economic wellbeing, leading to real HCD.
\end{abstract}

The present study explores whether existing agricultural value chains induce uniform HCD among farmers of paddy, dry chilli, sugarcane and marigold which are being cultivated and traded in varied formats in Karnataka. The outcome of the study confirms that efficient value chain that provides free and fair opportunities for farmers to trade at farm gate is an important factor that drives HCD among farmers.

\section{KEYWORDS}

HCD, Agricultural Value Chains, Farmers education, Distress selling, Livelihood, Social belongingness

\section{INTRODUCTION}

In the era of growing integration of global economy, developing countries find huge opportunity to register economic and income growth to address their unescapable issues of poverty and social inequality. In this context we find many nations of the developing world, spending on education, skill development and human hygiene of their citizens in order to equip them to take on the challenges of the world or to say in singular sense that the country is spending on its "Human Capital Development". In contrast, there are evidences again from developing nations that with the available status of human capital, they are reaching high levels of productivity and profit in selling their goods and services both in domestic and global market and this tendency is observed in most of the countries with agrarian economy. For example the export of agricultural commodities from India, China, Vietnam, to name a few has increased substantially above $200 \%$ in last 20 years (post liberalization period) and many scholars attributed this success to the robust supply chain practices and sensible management of agricultural value chains in respective countries. Thus on one hand developing agrarian economies are spending on their HCD and on the other hand making profits with available agricultural human capital and better supply chain practices. 
Based on the empirical research conducted in Karnataka (India), we intend to investigate whether human capital development as envisaged by the government in developing countries (with agrarian economies) or the value chain management of agricultural products is instrumental in creating new avenues of growth of economy and income. We also wish to know if there is any interplay between HCD and VCM and in addition reporting for any lapses in existing policies and practices which are obstructing either the development of human capital or the performance of agricultural value chains.

\section{REVIEW OF LITERATURE}

The following section presents the brief review of documented literature in the fields of HCD and VCM to state the objective of the study. The sequence follow the order of literature on HCD, that of VCM and some practically proven cases of VCM.

Organisation for Economic Co-operation and Development (OECD), 2001 [1] defined HCD in its report as "The knowledge, skills, competencies and attributes embodied in individuals that facilitate the creation of personal, social and economic well-being". The second quotation of the previously cited OECD (2001) states "Human and social capital are closely related to the way in which institutions and political and social arrangements impact on society. However the various elements need to be carefully distinguished, since human capital resides in individuals; Social capital resides in social relations and Political, institutional and legal arrangements describe the rules and institutions in which human and social capital work"[2]

T.W. Schultz (1961) one of the leaders of development of human capital of 1970s' called attention of the world about the role of human capital formation in economic growth and stated that it is simply not possible to have the fruits of modern agriculture and the abundance of modern industry without making large investments in human beings. Schultz (1980) [3] considers human capital formation as an important means for dealing with the problem of persistent poverty which is largely concentrated in the rural areas of developing countries.

Gary Becker (1962) [4] defined Human capital as an investment in education, training, and health and proposed the most sophisticated theoretical and empirical analysis of investment in people (1964) and developed a mathematical model of on-the job training and extends it to schooling and other forms of investment in people.

Choudhury D.P. (1972) [5] elaborated on farmer's education as a means of human capital in agriculture driven countries if it enables him to acquire ability to decode new information - know what, why, where; evaluate costs and benefits of alternative sources of economically useful information; Ability to choose optimum combinations of crops, new inputs and agricultural practices in least number of trials and to perform agricultural operations more effectively in economic sense, i.e., ability to produce more from a given amount of inputs.

Janine Nahapiet; Sumantra Ghoshal (1998) [6] in their contribution towards organizational development prove through the literature evidences that intellectual capital influence social capital and the organizations which foster the environment of developing these capitals reap market advantages of growth through innovation besides implied human capital development. The authors through a model, show that human capital hypothetically relates different dimensions of social capital and main mechanisms and processes necessary for the creation of intellectual capital.

Ployhart, Robert E.; Moliterno, Thomas P (2011) [7] defined human capital as a unit-level resource that is created from the emergence of individuals' knowledge, skills, abilities, or other 
characteristics. The authors provided new approach to the conceptualization of the human capital resource by developing a multilevel model connecting micro, intermediate, and macro levels of scholarship. The model provides new insights into how strategically valuable human capital resources have their origins in the psychological attributes of individuals and are transformed through unit-level processes.

Mahoney, Joseph T.; Kor, Yasemin Y. (2015) [8] elaborated on how the human capital perspective on value creation can be advanced by joining the capabilities and governance approaches. Reviewing the pitfalls and shortcomings of a traditional shareholder model in today's business context, the authors discuss about the mechanisms by which the firm-specific human capital development process can be stimulated and protected in enhancing a firm's core competencies (Hamel, Prahalad C.K 1994)

Subbarao Srinivas P. (2008) [9] finds that in developing nations, FDI inflows create a potential for spill-overs of knowledge to the local labor force and it is the host country's level of human capital determines the volume of FDI it can attract and the extent to which the local firms can absorb the spill-over techniques. Concluding on the policy requirement of host countries to attract FDI, the author finds that the policies adopted by such a country should create an environment supportive of innovation and skill upgrading and such policies cannot be uniform for all countries and depend upon the firms that are part of global competition network who will have more incentives to invest in training and education of their employees.

Raphael Kaplinsky \& Mike Morris (2000) [10] in their hand book for value chain research, defined simple value chain as description of full range of activities which are required to bring a product or service from conception, through the different phases of production (involving a combination of physical transformation and the input of various producer services), delivery to final consumers, and final disposal after use. Stating the need for VCA in the era of rapid globalization the authors state three set of reasons (i) With the growing division of labour and the global dispersion of the production of components, systemic competitiveness has become increasingly important (ii) Efficiency in production is only a necessary condition for successfully penetrating global markets and (iii) Entry into global markets which allows for sustained income growth - that is, making the best of globalisation - requires an understanding of dynamic factors within the whole value chain.

Gereffi, G. (1994) [11], introducing the concept of global value chains focused on the power relations which are imbedded in value chain analysis. By explicitly focusing on the coordination of globally dispersed, but linked, production systems, the author confirmed that many chains are characterised by a dominant party (or sometimes parties) who determine the overall character of the chain, and as lead firm(s) becomes responsible for upgrading activities within individual links and coordinating interaction between the links as explained under judicial and executive governance.

Raphael Kaplinsky \& Mike Morris (2000) note three reasons for the importance of value chain analysis in the era of rapid globalization. They are (i) with the growing division of labour and the global dispersion of the production of components, systemic competitiveness has become increasingly important (2) Efficiency in production is only a necessary condition for successfully penetrating global markets (3) Entry into global markets which allows for sustained income growth - that is, making the best of globalisation - requires an understanding of dynamic factors within the whole value chain

Fiter, R. and Kaplinsky, R. (2001) [12] applied value-chain analysis to an agricultural commodity which is in the process of significant change in final product markets. It is hypothesised that similar trends can be observed in other agricultural-based value chains. 
Fromma, I. and Dubónb, J.A. (2006) [13], in their study to analyse how small coffee farmers are integrating themselves in the value chain in Honduras, finds the evidence of small producers and exporters in developing countries inserting themselves successfully in global scale agricultural value chains.

Schmitz, Hubert (1995) [14], analysed leather shoe value chain, focusing on producers in Brazil and China and buyers in the USA. The study revealed that in case of Brazil, the large volume US buyers were quite happy for the firms to deepen their value added in production; indeed they both encouraged and promoted this thus noting a fact that particular forms of connectedness will affect the extent to which firms can upgrade in global chains.

Prahalad C.K.(2004) [15] upon interaction with farmers under e-chaupal, value chain initiative of ITC finds that when the poor are converted into consumers, they get more access to products and services. They acquire the dignity of attention and choices from the private sector that were previously reserved for the middle-class and rich. By having independent choice of choosing their customers through quick information sharing on e-platform, he enjoys a kind of liberty and dignity.

\section{OBJECTIVE}

The available documented research on human capital development (HCD) emphasize the need for human capital development at an individual level, firm level and society at large to envisage constructive development of nations. The definition of HCD from its origin which focused on individual's "Knowledge, Education and Health" (Becker, 1964; Schultz, 1961) has revised itself from time to time into a more comprehensive viewpoints such as "an individual's stock of knowledge, skills, and abilities" (Coff and Kryscynski 2011) or "A unit level resource that is created from the emergence of individuals' knowledge, skills, abilities and other characteristics (KSAOs)" (Ployhart and Moliterno 2011).

By and large, the research literature evolved in the area of HCD in developed countries focused on human capital from the perspective of individuals and their input to developing organizations at firm level besides contributing enormously to the disciplines like Human Resource Management and Strategy. Contemporary research in human capital focus on developing human capital resources at unit and multiunit level leading to the evolution of new discipline of strategic human capital development which finds its relevance in providing competitive advantage (Ployhart and Moliterno 2011) to the firms and nations in the today's context of innovation driven economies across the globe.

On the other hand, the literature available from the origin of developing countries discuss about human capital development of agriculture based economies on dimensions like economic development of farmers, fairness in trade, education and training of farmers to generate and save wealth for their better quality of life strongly advocate the need for free and quality education to the poor and rural farmers (Choudhury D.P 2001) across nations for HCD.

Proponents of agricultural value chains across the globe have proved with successful evidences in many nations that trained farmers with transparent and executive governance (Raphael Kaplinsky, Morris 2000) in administering the agricultural value chains can provide competitive advantage thereby becoming wealth creators at the bottom of the pyramid (Prahalad C.K 2001) irrespective of the context being developed or developing nation.

The present study tries to converge the concept of HCD as deliberated in developing nations and that of agricultural value chains to know the real contributor to HCD among farmers. Thus it is 
an empirical research carried out to consolidate the importance of education, training and exposure of farmers to transparent value chains towards HCD in the field of agriculture.

\section{DATa \& MeThodology}

For the purpose, four agricultural produces viz., Paddy (conventional agriculture with poor value chain), Sugarcane (government regulated, conventional agriculture with moderate value chain), Dry Chilly (conventional agriculture with aggressive value chain) and Marigold flowers (contract farming with pre-structured value chain) were selected to study their entire value chain, supply chain practices being followed by farmers and other intermediaries. With the help of tested questionnaire, the responses were collected from 382 farmers across the state of Karnataka (India) to trace their socio-economic status, prevailing supply chain practices in selling their agricultural produce and human capital development as perceived by them. The sampling technique adopted was probability-proportional-to size (PPS) and the sample units are drawn from the clusters identified in each district by the department for estimation of cost of cultivation for 14 principal crops in Karnakata based on the basic information on production statistics of crops under study in Karnataka (Table-1). The data analysis is carried out using tools like ANOVA, Multi-factor comparisons with Post Hoc test and Kruskal-Wallis test to draw statistical inferences. Data collection period was during the year 2013 soon after harvesting and selling of each agricultural product under study.

Table-1 Production statistics \& samples of selected agricultural products under study

\begin{tabular}{|l|c|c|c|c|}
\hline \multicolumn{1}{|c|}{ Estimates } & Rice & Sugarcane & Dry chilly & Marigold \\
\hline Total Area under cultivation (Hectares) & 1486478 & 496742 & 138711 & 2833 \\
\hline Districts Covered & 24 & 12 & 8 & 4 \\
\hline No. of sample respondents & 196 & 81 & 61 & 44 \\
\hline
\end{tabular}

*Source: Directorate of Economics and Statistics, Bengaluru for the year 2012-13

\subsection{Development of HCD measurement tool}

Though the conceptual definition of human capital is clear, its measurement is difficult as it is practically impossible to see individual skill and to design a metric that is comparable across individuals and different social set ups. Hence, many alternative measures of human capital have been proposed in the empirical literature, such as literacy rates (Azariadis and Drazen 1990)[16]; school enrolment rates (Barro 1991, Mankiw et al. 1992[17]); years of schooling (Barro and Lee 1996, 2001, and 2010; Cohen and Soto 2007); and test scores (Hanushek and Kimko 2000 [18]). Still in totality none of these measures prove to be complete, for eg., the literacy rate, which measures the proportion of the population who can read and write, it does not measure the educational attainment or skill level of the group of working people. Similarly, school enrolment rate is a relevant metric only for school going children and has little relevance for the community as a whole. Thus even though years of schooling can reasonably capture the human capital stock of the working group of people, it is just an indication of quantity of human capital without any clue about skill level of the workforce.

For the present study, the definition of human capital is considered to be an outcome of three broad dimensions viz., Education, Economic and Social well-being on individuals. The state government of Karnataka and government of India have set up various education programmes, rural banks, cooperative societies and such other forums to ensure HCD among farmers and that are being utilized by the farmers. The tool to measure HCD among the farmers under study is developed based on the response of farmers towards usage of education facilities, income 
generation opportunities and socializing within community to share their learning through forums like agriculture fairs and exhibitions organized at different levels by agriculture universities, government and private institutes for the development and well-being of farmers. It is in the form of 10 positive statements exposed to formers to respond on available facilities of Education, Economic wellbeing and Social wellbeing and the responses so collected on 5- point scale (Table-2) were used for further analysis.

Table-2 Assessment tool of Human Capital Development (Eg. for paddy formers)

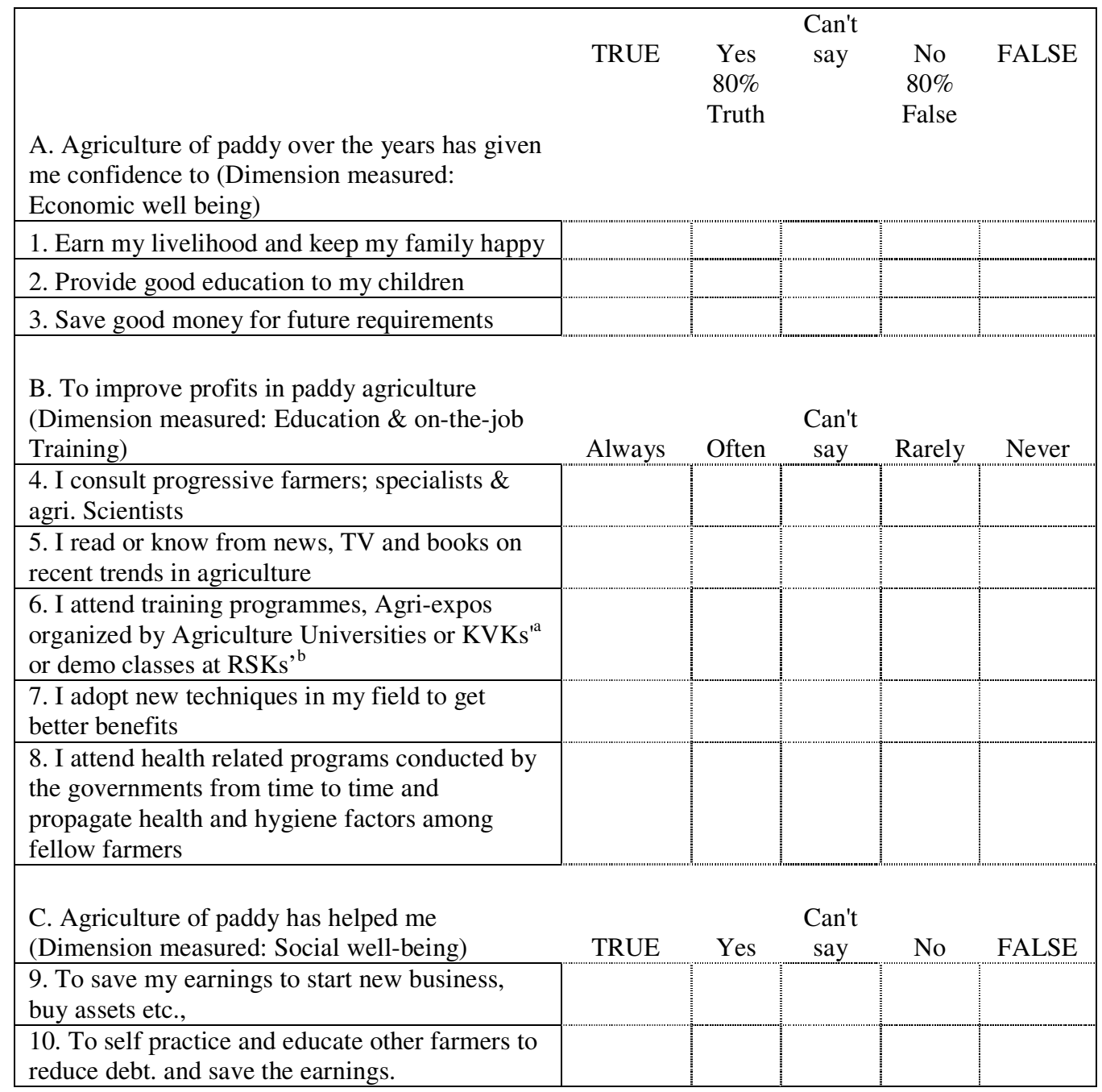

The question format of Table- 2 was circulated among the farmers along with the main questionnaire (Annexure) to know their socio-economic background and prevailing supply chain practices. The comparative analysis of socio economic factors and value chain related information that influence HCD of farmers under study are presented in the following sections.

\subsection{Brief introduction agricultural value chains under study in the state.}

Paddy: Involves $78 \%$ of small and marginal farmers; Rice mill owners and agents are the usual vendors of farmers; cultivated across 24 out of 31 districts of the state; No adequate storage capacity at farmer level soon after harvesting; $69 \%$ of sales at farm gate to mill owners and 
agents; variety and quality specific buyers are less; More than $90 \%$ demand is from local markets; 53\% farmers receive part payment towards delivery of paddy at farm gate. All value addition and processing of by-products start only after initial milling. So no other industry induce demand at farm gate except agents and mill owners. No adequate storage capacity at farmer level to increase the sales revenue. Highest value build-up of about $45 \%$ (Nagaraj BV, Dr. Y.T. Krishnegowda 2015 [21]) International Journal of Managing Value and Supply Chains, Vol.6, Mar 2015at the end of milling.

Sugarcane*: About $62 \%$ farmers have small and marginal land holding; cane production is spread across 12 districts of the state; complete supply chain is regulated by the government; value mark-up of above $80 \%$; correction in price of sugar is cyclic in every 3-4 years which lead to over stocking and part payment by sugar plants. Part payment is found to be about $43 \%$ and this has been accumulated since 5-6 years and has become a big arrears to be paid to the farmers; this has lead to a kind of dissatisfaction to the farmers; utilization rate of sugar production plants is about $60 \%$; farmers keep switching to other crops because of these reasons.

Dry chilli*: Involves about $57 \%$ of small and marginal farmers; Karnataka is a home for cultivating famous high colour, low pungency varieties called Byadagi Dabbi and Kaddi known for its unique flavor and highest color value in the world and thus owns GI tag. World spice leaders like Synthite, AVT Mcormick ingardients Pvt. Ltd., Kancor Colors Ltd., operate in the state with Integrated Pest Control based contract farming in some districts of the state and have solvent extraction facilities. So huge demand for the chilli cultivated in domestic, national and international markets; product portfolio is huge; pungency as well as colour have distinct value in international markets. Wholesalers from across the country, packaged chilli powder manufacturers, oleoresin manufactures are the direct point of contact to the farmer at farm gate and hence the farmers enjoy higher bargaining power in selecting the customer who can give better value for the produce. Sorting and cleaning at farm gate attracts better value by the customers. Farmers enjoy crop rotation and intercropping with desi cotton. So opportunity to make profit is available at the farm gate. Value mark-up is more than $200 \%$ with value added products like chilli oleoresin and capsaicin which have high demand in the international market.

Marigold flowers*: About 59\% pf small and marginal farmers in the state are involved in cultivation; there are 6 companies running in the state with contract farming of marigold. Contract farming pioneers and exporters of natural colours like Synthite, Katra Phytochem Pvt. Ltd., Plant Lipids to name a few operate in the state with contract farming and solvent extraction facilities. All assistance regarding the crop is provided by the Cos. No transportation cost; Predetermined price and revenue to the farmers; well managed and coordinated support of contracting firm in educating and training the farmers in cultivating new variety of marigold, highly efficient supply chain practices to ensure deliver of high quality farm fresh flowers to the processing unit; used as rotation crop with guaranteed return in a short span of three months. Value build up is more than $200 \%$ with marigold oleoresin, Lutein ester and trans-Lutein which are value added products from marigold oleoresin used as nutraceuticals of high demand in the international markets of US, Japan, UK, Europe and Germany.

(* - Research findings of authors)

\subsection{Supply Chain characteristics of crops under study}

Though all the four value chains are quite different in their form, there can be some learning insights through transactional and comparative studies. So the following section deals with comparative analysis of these four agricultural value chains, intended to derive some transactional initiatives that may befit to minimize value loss in existing or other similar agricultural value chains. 
Table-3 Comparison based on Socio-Economic factors

\begin{tabular}{|c|c|c|c|c|}
\hline Parameters & Marigold & Paddy & Dry Chilly & Sugarcane \\
\hline Marginal $^{\mathrm{c}}$ \& Small Farmers ${ }^{\mathrm{d}}(\%)$ & 59 & 78 & 57 & 62 \\
\hline Large Farmers $^{\mathrm{e}}(\%)$ & 9 & 6 & 10 & 15 \\
\hline Education Level - Nil / Primary (\%) & 27 & 38 & 39 & 30 \\
\hline Education Level - Graduation (\%) & 32 & 22 & 16 & 28 \\
\hline Avg. Family Size (Nos.) & 6.39 & 6.5 & 6.0 & 6.78 \\
\hline $\begin{array}{l}\text { Avg. no. of school going children in a } \\
\text { family }\end{array}$ & 1 & 2 & 1 & 2 \\
\hline
\end{tabular}

Demographically, share of marginal and small land holding farmers stands around $60 \%$ and the same is high in case paddy; involvement of large farmers is seen in sugarcane farming. The education level at Nil/primary education remains almost same at $30 \%$ across all crops. The proportion of graduates in marigold farming is highest with $32 \%$ and the same is lowest for chilly farming with $16 \%$. However it is found from main survey that chilly farmers enjoy more freedom among others considered under study.

Table-4 Comparison based on agricultural practices

\begin{tabular}{|l|c|c|c|c|}
\hline Parameters & Marigold & Paddy & Dry Chilly & Sugarcane \\
\hline Years associated with the crop & 3.15 & 7.6 & 6.1 & 5.7 \\
\hline Avg. Area cultivated (Acre) & 1.45 & 3.8 & 4.4 & 4.0 \\
\hline Intercropping & No & No & Yes & No \\
\hline Crop Rotation & Yes & Yes & Yes & Yes \\
\hline Yield (Kg/MT per Acre) & 7.35 & 2.5 & 728.6 & 40.0 \\
\hline
\end{tabular}

(Source: Research findings of authors)

The notables of the above comparison are the average acreage for different crops. The average area cultivated per former for marigold just 1.45 acre since farmers go for marigold as a rotation crop and as a means of regular weekly income paid by the contracting firm which helps financial needs of other crops in remaining part of their field. Intercropping and crop rotation is efficiently managed by chilli farmers as a traditional practice in the areas of north Karnataka, where farmers continuously grow chilli with onion and rotate the crop by desi cotton; all the cash crops with only rain fed land.

Table-5 Comparison based on product selling practices of farmers

\begin{tabular}{|l|c|c|c|c|}
\hline Parameters & Marigold & Paddy & Dry Chilly & Sugarcane \\
\hline Sales through APMC/to Co (\%) & 90 & 31 & 72 & 90 \\
\hline Direct selling at farm gate (\%) & 10 & 69 & 28 & 10 \\
\hline Full payment received (\%) & 100 & 47 & 61 & 57 \\
\hline Part payment received (\%) & 0 & 53 & 39 & 43 \\
\hline
\end{tabular}

(Source: Research findings of authors)

Paddy is sold directly to the party in $69 \%$ of cases and dry chilly in $28 \%$ of cases. Here the effect of these behaviours lead to multiple problems like farmer loosing opportunity to sell at right price after completely drying the commodity, APMC (Agriculture Produce Marketing Committee, government body that looks after marketing of agricultural goods in India) loosing revenue and very important and detrimental effect is formation of network between farmers and the agents / stockists, which do not stop after transaction but continues by each parties helping each other financially i.e., agents go on practicing part payment; start giving balance amount to the farmer whenever required by the farmer; this in fact gives time to the agents in arranging 
finance but sounds as if they are helping farmers in time; this happens without interest calculated on remaining balance amount. Further the group of stockists go on providing farmers advance amount before the season beginning so that that the farmers are made loyal to sell their produce after harvesting. This kind of continued relationship leads to the formation of interest groups which starts politicking, violating healthy competition and avoiding good schemes for their vested interest. Also it can be seen that part payment percentage in case of paddy, dry chilli and sugarcane is respectively $53 \%, 39 \%$ and $43 \%$.

Table-6 Comparison based on Seasonality and benefit to the farmers

\begin{tabular}{|l|c|c|c|c|}
\hline Parameters & Marigold & Paddy & Dry Chilly & Sugarcane \\
\hline Duration of crop (months) & 4 & 5 & 8 & 12 \\
\hline No. of crops/year & 1 & 2 & 1 & 1 \\
\hline Earnings / Month /Acre (Rs.) & 2780 & 2552 & 2692 & 2872 \\
\hline HCD Score (Out of 5) & 3.5 & 3.0 & 3.6 & 3.1 \\
\hline
\end{tabular}

(Source: Research findings of authors)

On human capital development (HCD) assessment, dry chilli farmers enjoy much of the liberty as the demand for their produce is from many potential users other than direct consumers for food purpose. Here bargaining ability of the farmer is high and hence HCD is rated very good. The important point to note is though for sugarcane government is highly involved, HCD score is just marginal. This indicates a kind of policy imbalance in managing industries as well as farmers and farmers are made losers in the end as they have to grow, sell their produce and keep waiting for balance payment across the year. That in case of paddy it is pathetic as most of the farmers involved in paddy agriculture are marginal and small land holding farmers. It is because of the system-wide deficiency in poorly managing post-harvest scenario of paddy and letting too many intermediaries into the value chain. The case of marigold is quite different as the complete show is managed by contracting organizations. HCD rate being 3.5 indicates that farmers need and like a kind of educated farming with a control mechanism that assures no power imbalance across the value chain and the trade is maintained transparent and fair with full payment for the agricultural produce when sold from farm to factory.

\section{DATA ANALYSIS USING INFERENTIAL STATISTICS}

Data collected in the main research regarding socio-economic factors like farmers' education level, family size, number of school going children in a family, presence of financial liability during cultivation of the crop and land holding pattern, which influence farmers in the decision making process to sell their agricultural produce after harvesting.

The data collected on these factors through farmers' response (scores on 5 point scale) in a field survey were tested for the equality of their mean scores across all crops under study using 1 way ANOVA or Kruskal-Wallis $\left(\mathrm{K}-\mathrm{W} \chi^{2}\right)$ test with Tukey's Post-Hoc analysis for comparison between the groups. Summary of the same is presented in Table-7 and the discussion thereon. 
Table-7 Socio-economic factors influencing farmers of the crops under study

\begin{tabular}{|c|c|c|c|}
\hline Hyptheses & $\begin{array}{l}\text { F-Ratio / K- } \\
\text { W }\left(\chi^{2}\right)\end{array}$ & P-Value & $\begin{array}{l}\text { P-Value of Post Hoc } \\
\text { test /Remark }\end{array}$ \\
\hline $\begin{array}{l}\mathrm{H}_{01} \text { : Education level of farmers remain same } \\
\text { for different crops under study }\end{array}$ & $\begin{array}{l}6.61 \\
\left(\mathrm{~K}-\mathrm{W} \chi^{2}\right)\end{array}$ & .09 & \\
\hline $\begin{array}{l}\mathrm{H}_{02} \text { : Family size of farmers remain same for } \\
\text { different crops under study }\end{array}$ & $\begin{array}{l}3.73 \\
\text { (F-ratio) }\end{array}$ & $0.01 *$ & $\begin{array}{l}0.00 * \text { for chilli and } \\
\text { sugarcane }\end{array}$ \\
\hline $\begin{array}{l}\mathrm{H}_{03}: \text { No. of school going children in a } \\
\text { farmer's family remain same for different } \\
\text { crops under study }\end{array}$ & $\begin{array}{l}3.73 \\
\text { (F-ratio) }\end{array}$ & $0.01 *$ & $\begin{array}{l}0.00 * \text { for paddy and } \\
\text { sugarcane }\end{array}$ \\
\hline $\begin{array}{l}\mathrm{H}_{04} \text { : Financial liability of farmers remain } \\
\text { same for different crops under study }\end{array}$ & $\begin{array}{l}31.20 \\
\left(\mathrm{~K}-\mathrm{W} \chi^{2}\right)\end{array}$ & $0.00^{*}$ & \\
\hline $\begin{array}{l}\mathrm{H}_{05} \text { : Land holding pattern of farmers remain } \\
\text { same for different crops under study }\end{array}$ & $\begin{array}{l}24.36 \\
\left(\mathrm{~K}-\mathrm{W} \chi^{2}\right)\end{array}$ & $0.00^{*}$ & \\
\hline
\end{tabular}

$*<0.05$ (Source: Research findings of authors)

It is evident from the Table-7 that on an average, education level across formers of all crops under study remains same. However there is a significant difference among formers of crops under consideration on other socio economic factors viz., family size, no. of school going children in a family, financial liabilities and land holding pattern. The next level of investigation is to check whether these socio-economic factors influence selling behaviour of farmers after harvesting of crop, which is a crucial part of agricultural value chains where farmers exercise their decision making ability to create wealth.

At this juncture, farmers make distress selling decisions due to the compelling socio-economic factors (discussed above) or due to prevailing market dynamics (peer pressure) during harvesting which may include questions like whom to sell, when to sell, in what form or to which party the produce to be sold in order to get the perceived benefits. This helps in some cases to gain better benefits but in most of the cases losses for small and marginal farmers as the quantity that they grow is less.

The tendency of distress selling is observed in the cases of paddy and dry chilli harvesting. This do not exist in case of farmers of marigold flowers as they are under trade contract with the respective contract farming company and company will buy the flowers soon after harvesting at farm gate. Distress selling is not observed even in the case of sugarcane as more than $70 \%$ farmers are bound through a contract; but in remaining $30 \%$ of cases farmers do make distress sale during peak seasons of harvesting when farmers are made to wait for his turn to deliver the cane to the factory after harvesting. However the distress selling of sugar cane will not lead to value loss if taken to the next factory premises without quality deterioration as the price is regulated by the government. This behaviour is observed in districts of Belgaum and part of Bijapur where concentration of sugar mills is more. The influencing factors for distress selling in case of paddy and chilli is found through association studies using $\chi^{2}-$ test. Table- 8 gives the set of hypotheses stated for distress selling/sale and its influencing factors to verify their significance in causing distress selling/sales of paddy and chilli after harvesting. 
International Journal of Managing Value and Supply Chains (IJMVSC) Vol. 7, No. 3, September 2016

Table-8 Socio-economic and market driven factors influencing farmers to sell their crop after harvesting

\begin{tabular}{|l|c|c|}
\hline Hyptheses & \multicolumn{2}{|c|}{$\chi^{2}(\mathrm{P}-$ Value corresponding to } \\
\cline { 2 - 3 } & Paddy & Chilli \\
\hline $\begin{array}{l}\text { Distress selling / sales and } \\
\mathrm{H}_{06} \text { : family size of farmer are independent }\end{array}$ & 0.29 & 0.65 \\
\hline $\begin{array}{l}\mathrm{H}_{07}: \text { no. of school going children in farmer's family are } \\
\text { independent }\end{array}$ & 0.77 & 0.82 \\
\hline $\mathrm{H}_{08}$ : education level of the farmer are independent & 0.66 & 0.72 \\
\hline $\mathrm{H}_{09}$ : financial liabilities of the farmer are independent & $0.03^{*}$ & $0.04^{*}$ \\
\hline $\mathrm{H}_{10}$ : land holding patterns are independent & $0.00^{*}$ & 0.47 \\
\hline $\mathrm{H}_{11}$ : the dependency on other parallel crop are independent & & \\
& $0.00^{*}$ & 0.81 \\
\hline $\mathrm{H}_{12}:$ party to whom it is being sold are independent & $0.02^{*}$ & $0.00^{*}$ \\
\hline $\begin{array}{l}\mathrm{H}_{13}: \text { type of payment (part / full) by the customer are } \\
\text { independent }\end{array}$ & 0.18 & $0.03^{*}$ \\
\hline $\mathrm{H}_{14}:$ variety of product being sold are independent & N.A. & $0.01^{*}$ \\
\hline $\mathrm{H}_{15}$ : the form in which it is to sold are independent & N.A. & $0.01^{*}$ \\
\hline
\end{tabular}

$*<0.05$ (Source: Research findings of authors)

Note that in Table-8, hypotheses from $\mathrm{H}_{06}$ to $\mathrm{H}_{10}$ are stated with socio-economic factors discussed earlier whereas hypotheses from $\mathrm{H}_{11}$ to $\mathrm{H}_{15}$ are stated with those factors which prevail during the time of harvesting and compel farmer to sell the goods. It can be further understood looking at the significant p-values that the stated socio economic factors such as financial liabilities and land holding pattern are the only influencing factors for the selling behaviour of farmer whereas many factors which exist due to market dynamics viz., whom to sell, when to sell, in which form to sell, which variety to sell and dependency on other crops make crucial impact on selling decision of farmers after harvesting paddy and chilli. Here socio-economic factors represent stock of human capital in farmers and response of farmer in the form of selling decision to the market driven factors is the cognitive outcome of the human capital thus influencing good/bad decision. Thus we see the concurrence with the model demonstrated by Ployhart, Robert E.; Moliterno (2011)

The third part of data analysis uses the data collected to measure human capital development on 5-point scale using the tool discussed under table-2 to test whether the aggregate scores on different dimensions of HCD i.e., Education, economic wellbeing and social wellbeing as perceived by farmers differ across four crops under study. Table- 9 is the summary of F-tests (ANOVA) to know whether mean scores of different dimensions of HCD are same across farmers of all crops under study.

Table-9 Three dimensions of HCD among farmers of the crops under study

\begin{tabular}{|l|l|l|l|}
\hline Hyptheses & F-Ratio & P-Value & Remark \\
\hline $\begin{array}{l}\mathrm{H}_{16}: \text { Mean scores on economic } \\
\text { wellbeing dimension of HCD are same } \\
\text { among farmers of all crops under study }\end{array}$ & 31.57 & $0.00^{*}$ & $\begin{array}{l}\text { Marigold \& Chilli; } \\
\text { Paddy \& Sugarcane } \\
\text { make 2 homogenous } \\
\text { subsets }\end{array}$ \\
\hline $\begin{array}{l}\mathrm{H}_{17}: \text { Mean scores on education } \\
\text { dimension of HCD are same among } \\
\text { farmers of all crops under study }\end{array}$ & 14.04 & $0.00^{*}$ & $\begin{array}{l}\text { Marigold \& Chilli; } \\
\text { Paddy \& Sugarcane } \\
\text { make 2 homogenous } \\
\text { subsets }\end{array}$ \\
\hline $\begin{array}{l}\mathrm{H}_{18}: \text { Mean scores on social wellbeing } \\
\text { dimension of HCD are same among } \\
\text { farmers of all crops under study }\end{array}$ & 6.15 & $0.00 *$ & $\begin{array}{l}\text { Marigold \& Chilli; } \\
\text { Paddy \& Sugarcane } \\
\text { make 2 homogenous } \\
\text { subsets }\end{array}$ \\
\hline
\end{tabular}


$*<0.05$ (Source: Research findings of authors)

It is to be noted from Table- 9 that there is a significant difference ( $p$-value $=0.000$ ) in perceived scores towards three dimensions of human capital among farmers of all crops under study. However the aggregate scores are similar on all aspects of HCD for crops dry chilli and marigold (as evidenced by homogenous subsets indicated by Tukay's Post-Hoc analysis). This can be attributed to the fact that marigold is cultivated with contract farming and dry chilli cultivation and marketing provides much of variety and liberty to the farmers. For paddy and sugarcane the scores almost behave similarly (another homogenous subset found in the analysis) with low scores due to traditional supply chain practices. Market interaction of farmers in case of paddy and sugarcane is limited to mill-owners, agents and sugar factory personnel.

In line with the result of above inferential statistics (Table 7, 8 and 9), aggregate scores obtained from the responses of farmers to the 10 positive statements covering three dimensions of human capital development against number respondents (in percentage) for all agricultural products under study when plotted on XY-plane gives Figure-1.

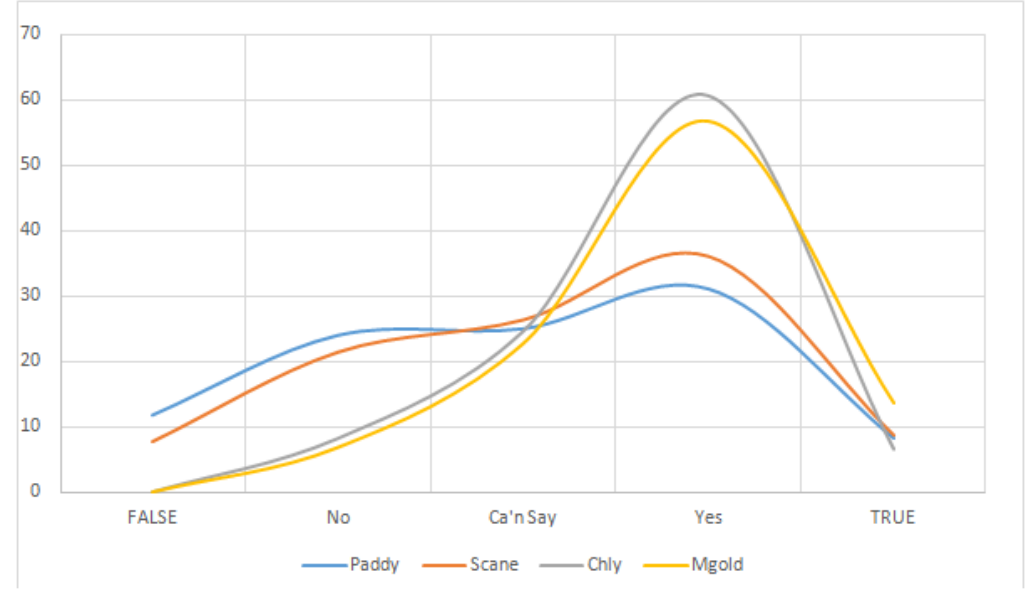

(Source: Research findings of authors)

Figure-1 Comparative analysis of HCD among farmers of agricultural products under study

Thus it can be concluded that marigold and chilly value chains seem to be more encouraging on human capital development scale when compared to those in other two value chains of paddy and sugarcane.

\section{DISCUSSION OF RESULTS}

It is evident from the study that, Human Capital Development is found to be better in farmers of marigold and dry chilli as compared to paddy and sugarcane. This result leads us to answer three questions.

1. Which factors influence most in measuring the outcome of human capital development in farmers?

2. Why value chains of marigold and chilli perceived to be encouraging crops on HCD scale and why not that for paddy and sugarcane? and to conclude

3. How the HCD be improved among farmers of paddy and sugar cane or in general any crop? 
Answering the first, it is found that only financial liabilities of farmers, land holding pattern among socio-economic factors do influence in selling decision made by the farmers and other factors like education of farmers, their family size, number of school going children in farmer's family, hardly make any impact on farmer's selling decision. Other factors like whom to sell? When and in which form to sell, type of payment (full/part), which variety (in case of chilli) to be sold to whom are some factors that are driven by the market dynamics which compel the farmers to make decisions at the time of harvesting; some of them turn out to be hasty and some prudent.

Hence HCD among farmers may be regarded as the net outcome of making best selling decision with the combined set of influencing factors; some of them socio-economic and some market driven. In fact the socio-economic factors like family size, education level of farmers, their financial liabilities, land holding pattern and number of school going children in a family build responsibility on a farmer to earn through agriculture and hence be treated structural constructs of human capital or stock of human capital within each farmer and the response of the farmer to the market driven situations is the cognitive outcome of the human capital already stocked in a farmer.

The best result of the decision made by the farmers is an outcome of how wisely the farmer uses his human capital in responding to the market driven factors which are not under anybody's control.

Answering the second, if we look at the value chains of marigold, the farmer enjoys the benefit of contract farming viz., assistance of contracting company right from seed distribution till the collection of the grown flowers at the farm gate, pre-determined price and 100\% payment for the produce soon after delivery of the crop. Thus there is a well defined support system which ensures guaranteed revenue generation apart from huge value build-up of over $200 \%$ and constant demand from international market.

In case of chilli, the farmer enjoys high bargaining power and transparent selling mechanism which drives all stake holders viz, agents, wholesale merchants, packaged chilli powder manufacturers, oleoresin manufacturers as $80 \%$ of chilli cultivated in Karnataka are of Byadgi variety, which attracts many competing customers at the farm gate. Other advantages to chilli farmers is that along with chilli they intercrop onion and rotate the crop in a year with desi cotton; all are cash crops. The farmer can sell chilli as green chilli if it has good price without waiting to get dried in the farm itself. In all situations the chilli farmer enjoys a kind of liberty to trade.

In case of paddy and sugarcane, farmers interact only with next line processors viz., mill owners, agents or sugar cos in most of the cases and these farmers will not be able to value add their products by themselves as it requires fool-proof storage facilities which are lacking in the state (in case of paddy). The part payment ratio in paddy and sugarcane is also high and demand for the produce is local. This always leads to poor or average income generation and it is cyclic every year as there are very bleak chances of leap jump in pricing so that the farmer gets benefitted. These are the set of reasons found through the study which indicate low HCD scores by paddy and sugarcane growing farmers.

Answering the third question based on the findings of present investigation is that, in order to ensure continuous growth in human capital development among farmers it is not enough if the governments and policy makers of HCD just give importance to provision of basic education and training programs needed to develop agriculture among farmers. In addition, policies are to be developed 
i) to expose farmers to different set of customers demanding variety of products, type of delivery, competitive market environments so that they equip their produce as per the new requirements of the world.

ii) to equip farmers with next line requirements of customers to be provided at the farm gate so that they realize better price for their produce. For eg., storage facilities, drying yards, winnowing, cleaning and packing facilities. At least one work shop having all these facilities under one roof per cluster of 5-6 villages will suffice the requirement to begin with. This gives real time training for farmers on how their income and livelihood can be improved.

iii) to eliminate formation of colonies in agricultural supply chain. Eg., mill owners and agents is a dynamic colony in paddy supply chain which commands a value build-up of more than $45 \%$ just for storing and milling the paddy.

iv) to ensure full payment by the buying parties once farmer delivers his agricultural produce.

\section{CONCLUSION}

This study reveals that, providing basic education and training to farmers, looking at enrolments at rural schools, one cannot access human capital development in farmers, more importantly not all human capital is produced by education (Knight 1996 [19]). As found from the study, factors like education level of farmers, family size, number of school going children in a family and land holding pattern ( $p>0.05$-insignificant, Table-8) do not play any role when farmer makes important decision of selling their agricultural produce, though they seem to define the economic status of the farmer. It is evident from the study that the market driven factors such as whom to sell, what is the type of payment (full/part), in which form to sell, which variety of product suits the customer $(* p<0.05$-significant, Table- 8$)$ influence farmers to make important decisions of wealth creation for their livelihood.

The study suggests two streams of activities to ensure continuous human capital development among farmers. From one stream of activities, structural constructs of human capital (concern about education, economic and social wellbeing) embedded in farmers (which intuitively / cognitively help them to make prospective decisions of sustainable income generation and social wellbeing) should be honed as per the changing needs of the market and society where farmer transacts for his livelihood. This can be done by exposing farmers to the customer needs of the entire value chain and provide them the required facilities to build value to the product at the farm gate.

From the other stream of activities, agricultural value chains are to be strengthened with strict legislative governance which ensures farmer friendly markets where farmer finds transparency, freedom to trade (Prahalad C.K. 2004 [20]) and enduring career path in agriculture. With the convergence of these two stream of activities a society can ensure everlasting and continually upgrading human capital development amongst farmers.

\section{ACKNOWLEDGEMENT}

We thankfully acknowledge the support and encouragement extended by various government and non-government institutions, agricultural scientists, farmers, stockists, vendors, industrial processors and our parent institutes in making this piece of work a meaningful research document. 
International Journal of Managing Value and Supply Chains (IJMVSC) Vol. 7, No. 3, September 2016

\section{REFERENCES}

1. OECD, Knowledge and Skills for Life: First Results from PISA. Executive Summary. OECD, 2001, Paris.

2. OECD, The Well-being of Nations: The Role of Human and Social Capital. OECD, 2001, Paris.

3. Schultz T. 1961. Investment in human capital. The American Economic Review. Princeton.1

4. G.S. Becker, Human capital, New York, NY: Columbia University Press $1964 .$.

5. D. P. Chaudhri, Education in Production in Modernising Agriculture in Asian Under Developed Countries. Research Quarterly, 1972, 1:pp. 1-75

6. Janine Nahapiet; Sumantra Ghoshal, "Social Capital, Intellectual Capital, and the Organizational Advantage", The Academy of Management Review, 1998, 23: pp.242-268.

7. Ployhart, Robert E. Moliterno, Thomas P., Emergence Of The Human Capital Resource: A Multilevel Model. Academy of Management Review, 2011, 36:127-150.

8. Mahoney, Joseph T. Kor, Yasemin Y. Advancing the Human Capital Perspective on Value Creation by Joining Capabilities and Governance Approaches. Academy of Management Perspectives 2015, 29: pp. 296-308.

9. Subbarao, Srinivas P. 2008. FDI and Human Capital Development. W.P. No.2008-02-01.IIM Ahmadabad, India

10. Kaplinsky R. Mike Morris, A handbook of Value Chain Research, developed for IDRC, 2000, Institute of Development Studies

11. Gereffi, G. 1994. The Organization of Buyer-Driven Global Commodity Chains: How U. S. Retailers Shape Overseas Production Networks. Commodity Chains and Global Capitalism, London: Praeger.

12. Fiter, R. Kaplinsky, "Who gains from product rents as the coffee market becomes more differentiated? A value chain analysis', IDS Bulletin Paper, 2001.

13. J.A. Fromma, I. and Dubónb, "Upgrading and the Value Chain Analysis: The Case of Small-scale Coffee Farmers in Honduras', Conference on International Agricultural Research for Development, 2006. Tropentag.

14. Schmitz, Hubert. 1995. Small Shoemakers and Fordist Giants: Tales of a Supercluster, World Development, 1995, 23: pp. 9-26.

15. [15] Hamel G., Pralahad. C.K., Competing for the Future, Cambridge Mass, Harvard Business School Press 1994.

16. Azariadis Costas, Drazen Allan Threshold Externalities in Economic Development. The Quarterly Journal of Economics, 2000, 105: pp. 501-526

17. R. Barro, Economic growth in a cross section of countries. Quarterly Journal of Economics, 1991, 106: pp. 407-445.

18. Hanushek, Eric A. and Kimko, Dennis D., "Schooling, Labor-Force Quality, and the Growth of Nations', American Economic Review, 2000, 90: pp. 1184-1210.

19. Knight, John, Human Capital in Economic Develoment. Editorial Introduction. Oxford Bulletin of Economics and Statistics, 1996, 58: pp. 5-8.

20. Prahalad C.K., Wealth at the bottom of the pyramid. Wharton School Publishing, 2004. Pp.46-75

21. Nagaraj BV, Y.T. Krishnegowda, International Journal of Managing Value and Supply Chains, Vol.6, Mar 2015

http://www.icar.org.in/en/aboutus.htm : information retrieved on 15.3.2016

http://www.icar.org.in/en/krishi-vigyan-kendra.htm : information retrieved on 15.3.2016

http://raitamitra.kar.nic.in/ENG/index.asp : information retrieved on 15.3.2016 
International Journal of Managing Value and Supply Chains (IJMVSC) Vol. 7, No. 3, September 2016

\section{FOOTNOTES}

\section{a. KVKs'(Ref. Table-2): Krishi Vigyan Kendras /Agriculture Science Centres}

There are 642 Krishi Vigyan Kendras in the order of one KVK/district throughout India designed and nurtured by ICAR (Indian Council of Agricultural Research: is an autonomous organisation under the Department of Agricultural Research and Education (DARE), Ministry of Agriculture, Government of India. The Council is the apex body for co-ordinating, guiding and managing research and education in agriculture including horticulture, fisheries and animal sciences in the entire country. With 101 ICAR institutes and 71 agricultural universities spread across the country this is one of the largest national agricultural systems in the world).

Each KVK is situated in a place within a district with all infrastructural facilities, modern agricultural equipment, laboratory and land to demonstrate new techniques and research outcomes in the field to the farmers. Each KVK will consist of wing of agricultural scientists in the field of agriculture, horticulture/ floriculture, fisheries/ agronomy / plant pathology and so on with equipped laboratory, who work with the motive of reducing the time lag between generation of technology at the research institution and its application to the location specific farmer fields for increasing production, productivity and net farm income on a sustained basis with the mandate of "Application of technology/products through assessment, refinement and demonstration for adoption"

To achieve the mandate effectively, the following activities are envisaged for each KVK:

- On-farm testing to identify the location specificity of agricultural technologies under various farming systems.

- Frontline demonstrations to establish its production potentials on the farmers' fields.

- Training of farmers and extension personnel to update their knowledge and skills in modern agricultural technologies.

- Work as resource and knowledge centre of agricultural technologies for supporting initiatives of public, private and voluntary sector for improving the agricultural economy of the district.

There are 31 KVKs' under the ambit of 7 agricultural universities in Karnataka operating in all districts of the state.

\section{b. RSKs'(Ref. Table-2): Raita Sampark Kendras / Farmer Facilitation Centres}

The Department of Agriculture established Raita Sampark Kendras at Hobli (Hobli is a cluster of 1015 villages : each district will have about 20-25 Hoblis) level with the objective of providing updated crop production related knowhow, arrangement of critical agricultural inputs, primary soil and seed testing facilities and arranging interface with public and private sector technologies. These Kendras are established with the objectives

- To provide technical information on crop selection, crop production related know-how, market information etc., to farmers.

- To provide primary seed and soil testing facilities locally.

- To facilitate on site provision of critical inputs like seeds, bio-fertilizers and plant protection chemicals.

There are 747 Krishi Sampark Kendras operating in Karnataka.

c. Marginal Farmers (Ref. Table-3): Farmers having land holding of less than $1 \mathrm{Ha}$.

d. Small Farmers (Ref. Table-3): Farmers having land holding of 1-2 Ha.

e. Large Farmers (Ref. Table-3): Farmers having land holding of $10 \mathrm{Ha}$ or more. 
International Journal of Managing Value and Supply Chains (IJMVSC) Vol. 7, No. 3, September 2016

Author/s' names: Dr. Nagaraj BV ${ }^{1}$, Dr. YT Krishnegowda ${ }^{2}$

\section{Authors' Designations:}

1. Assistant Professor in the area of Operations

Kirloskar Institute of Advanced Management Studies

Yantrapur,

Harihar - 577601, Karnataka (INDIA)

08192-241269, Fax: 08192-241270

2. Professor \& HOD,

Department of Mechanical Engineering

Maharaja Institute of Technology,

Balavadi, Srirangapatna- 571438, Mandya / Mysuru (INDIA)

Telefax : 08236-292601 